\title{
PENGARUH REPUTASI DAN TANGGUNG JAWAB PERSONAL TERHADAP BUDGETARY SLACK
}

\author{
Jimmi Charles ${ }^{1}$, Jesica Handoko ${ }^{2)}$ \\ ${ }^{1,2)}$ Jurusan Akuntansi, Fakultas Bisnis, Universitas Katolik Widya Mandala Surabaya \\ Email: jimmicharles3@gmail.com
}

Diterima 18 Januari 2021 / Disetujui 13 Juli 2021

\begin{abstract}
The budget is one of the important elements used in making decisions for corporate financial planning in the future. This budget is to become a benchmark for the company in determining success in achieving its planned goals by making comparisons between actual data and data that the company had previously planned. So that the budget will always be used by the company to determine budget planning and evaluate performance by comparing the budget plans. However, there is a problem in the budget planning process where the budget is not planned according to the actual by a manager. This happens because there are conflicts of interest, where managers will be more concerned with themselves than the interests of the company. Therefore, the budget will turn into a bias so that it can cause a budgetary slack. This study aims to find the factors that influence budgetary slack, namely by testing the influence of the variable reputation and personal responsibility on budgetary slack. This study is an experimental study with the aim of seeing whether there is an effect of reputation and personal responsibility on budgetary slack. This experiment uses a $2 \times 2$ design with the 2017 and 2018 students of Widya Mandala Catholic University Surabaya as participants in this experiment. The instrument given to participants in this experiment was the translation of letters into numbers. The hypothesis in this experiment was tested using ANOVA analysis tool. The results of this experiment show that neither reputation nor personal responsibility can affect budgetary slack.
\end{abstract}

Keywords : Budgetary Slack; Personal Responsibility; Reputation.

ABSTRAK : Dalam sebuah perusahaan, anggaran merupakan salah satu elemen penting yang digunakan dalam pengambilan keputusan untuk perencanaan keuangan perusahaan dimasa depan. Kegunaan dari anggaran ini sendiri adalah menjadi tolak ukur bagi perusahaan dalam menentukan keberhasilan perusahaan dalam mencapai tujuan yang telah direncanakan dengan cara melakukan perbandingan antara data aktual dengan data yang telah direncanakan oleh perusahaan sebelumnya. Sehingga anggaran akan selalu digunakan oleh perusahaan untuk menentukan perencanaan anggaran dan melakukan evaluasi kinerja dengan membandingkan dari rencana anggaran tersebut. Namun terdapat sebuah masalah dalam proses perencanaan anggaran yang dimana anggaran tidak direncanakan sesuai dengan aktual oleh seorang manajer. Hal ini terjadi karena terdapat pembenturan kepentingan, dimana manajer akan lebih mementingkan diri sendiri daripada kepentingan maupun tujuan perusahaan. Maka dari itu, anggaran akan berubah menjadi bias sehingga dapat menimbulkan kesenjangan anggaran atau budgetary slack. Penelitian ini bertujuan untuk menemukan faktor yang mempengaruhi budgetary slack, yaitu dengan melakukan uji pengaruh variabel reputasi dan tanggung jawab personal terhadap budgetary slack. Penelitian ini merupakan penelitian eksperimen dengan tujuan untuk melihat apakah ada pengaruh yang ditimbulkan dari reputasi dan tanggung jawab personal terhadap budgetary slack. Eksperimen ini menggunakan desain 2×2 dengan mahasiswa S1 Universitas Katolik Widya Mandala Surabaya angkatan 2017 dan 2018 sebagai partisipan dalam eksperimen kali ini. Instrumen yang diberikan kepada partisipan dalam eksperimen ini adalah penerjemahan huruf kedalam angka. Hipotesis dalam eksperimen ini diuji dengan alat analisis ANOVA. Hasil dari eksperimen kali ini menunjukkan bahwa reputasi maupun tanggung jawab personal sendiri terbukti tidak dapat mempengaruhi budgetary slack.

Kata Kunci : Budgetary Slack, Reputasi, Tanggung Jawab Personal. 


\section{Pendahuluan}

Anggaran adalah perencanaan dana untuk dimasa mendatang, yang berguna untuk mengidentifikasi tujuan perusahaan dan tindakan yang dilakukan untuk mencapainya (Hansen dan Mowen, 2016:423). Perencanaan anggaran merupakan hal yang penting untuk perusahaan agar dapat menjalankan bisnisnya sehingga perusahaan dapat mencapai dan sesuai dengan tujuan perusahaan. Selain itu anggaran juga menjadi tolak ukur penting bagi perusahaan untuk melihat keberhasilan perusahaan dengan melihat kondisi keuangan perusahaan dari pendapatan dan biaya di dalam suatu laporan yang diberikan. Tujuan dari rencana anggaran yaitu sebagai penghubung dan penyelaras dengan rencana strategis perusahaan, terlibat dalam aktivitas dari lini-lini yang ada di dalam organisasi perusahaan, memberikan manajer tanggung jawab dan mendapatkan komitmen yang akan menjadi dasar evaluasi kinerja aktual manajer. Mengingat anggaran merupakan hal yang penting di dalam perusahaan, penyusunan anggaran harus benar-benar diperhatikan sehingga dapat benar-benar mendukung semua tingkatan dalam organisasi perusahaan.

Dalam participative budgeting, penyusunan anggaran melibatkan seorang manajer yang bertujuan agar dapat memberikan informasi-informasi mengenai operasional perusahaan. Manajer dapat memanfaatkan keadaan ini untuk membuat anggaran yang lebih menguntungkan diri sendiri seperti membuat anggaran mudah dicapai. Hal ini dilakukan untuk menunjukkan kinerja yang baik sehingga dinilai bagus oleh atasan mereka. Kondisi ini yang disebut manajer melakukan kesenjangan dalam anggaran atau budgetary slack. Dalam partisipasi ini semakin tinggi partisipasi penyusunan anggaran yang diberikan maka semakin besar pula manajer melakukan tindakan budgetary slack (Damayanti dan Wirasedana, 2014).

Budgetary slack timbul karena seorang manajer mempertimbangkan adanya pendapatan yang rendah ataupun biaya yang disengaja ditingkatkan (Hansen dan Mowen, 2016:448). Anthony dan Govindarajan (2011) mengatakan jika budgetary slack merupakan adanya perbedaan antara jumlah anggaran yang diajukan oleh manajer dengan jumlah estimasi yang terbaik dari perusahaan. Riswandari (2009) menjelaskan jika slack adalah tindakan menganggarkan pendapatan yang rendah dan biaya yang tinggi supaya target dapat mudah dicapai ataupun melampaui sehingga kinerja manajemen terlihat baik. Hal ini dilakukan supaya manajer dapat memperoleh bonus maupun kenaikan jabatan dari atasan mereka. Praktik budgetary slack dapat dikatakan sebagai hal yang tidak etis untuk dilakukan karena terdapatnya unsur pribadi dan tidak dilakukan dengan benar. Oleh karenanya penting bagi seorang atasan untuk mengetahui faktor-faktor apa saja yang dapat mempengaruhi budgetary slack sehingga dapat diketahui apa yang dapat dilakukan untuk meminimalkan budgetary slack.

Teori keagenan mengatakan terdapat dua individu prinsipal dan agen yang dimana prinsipal memberikan wewenang kepada agen untuk ikut dalam partisipasi anggaran dan pengambilan keputusan yang terbaik (Jensen dan Meckling, 1976). Supriyono (2018:63) menjelaskan hal yang sama dimana teori agensi adalah pendelegasian wewenang dari prinsipal kepada agen agar agen dapat mengambil keputusan sendiri. Tujuan seorang prinsipal memberikan atau mendelegasikan kuasa kepada agen untuk mengambil keputusan dikarenakan agen yang memiliki informasi yang lebih sehingga dapat membuat keputusan yang tepat dan benar supaya dapat memajukan perusahaan. Akan tetapi antara principal dengan agen sering terjadi konflik atau perbedaan kepentingan dan agen terkadang memikirkan kepentingan yang cenderung menguntungkan dirinya. Tidak sejalannya kepentingan seorang prinsipal dengan seorang agen inilah membuat seorang agen memberikan informasi yang bias untuk dapat menurunkan target produksi sehingga agen dapat dengan mudah mencapai target produksi. Dari sinilah timbulnya 
kesenjangan anggaran atau budgetary slack (Efrilna, 2018).

Teori atribusi menjelaskan bahwa perilaku seseorang ditentukan oleh dua faktor, yaitu faktor internal (berasal dari dalam diri seseorang) maupun faktor eksternal (berasal dari luar seseorang). Teori atribusi dalam penyusunan anggaran, dapat menentukan perilaku seseorang dalam melakukan penyusunan anggaran dimana ketika seseorang cenderung memiliki sikap yang positif maka akan berusaha untuk menghindari kegiatan yang tidak etis, seperti budgetary slack. Bila seseorang cenderung memiliki sikap yang negatif maka akan melakukan segala cara untuk dapat mencapai tujuannya yang bisa saja melakukan tindakan yang tidak etis, yaitu budgetary slack (Hudayati, 2002). Pada dasarnya teori atribusi ini meneliti dan menjelaskan bahwa terdapat dua faktor, yaitu faktor internal dan faktor eksternal dalam mempengaruhi perilaku manusia di dalam sebuah organisasi atau perusahaan, seperti bagaimana perilaku agen apabila mendapat tekanan atau pemberian metode insentif dari atasannya, atau bagaimana perilaku agen jika dia memiliki reputasi yang tinggi ataupun dia memiliki sikap dengan tanggung jawab yang tinggi pula sehingga dapat mempengaruhi tingkat terjadinya budgetary slack.

Penelitian ini berfokus pada faktor internal yaitu reputasi dan tanggung jawab personal (Abidin dan Sutrisna, 2016). Fokus pada faktor internal karena adanya hasil yang tidak konsisten dalam pengujianpengujian faktor internal, misalnya penelitian Steven (2002) menunjukkan faktor internal berpengaruh negatif pada budgetary slack sedangkan peneltian yang dilakukan Onsi (1973); Abidin dan Sutrisna (2016) menunjukkan faktor internal berpengaruh positif terhadap budgetary slack. Penelitian Nugrahani dan Sugiri (2004) menunjukkan hasil berbeda dengan penelitian oleh Abidin dan Sutrisna (2016). Untuk faktor eksternal beberapa penelitian terdahulu seperti pengaruh pemberian insentif terhadap budgetary slack telah menunjukkan konsistensi hasil seperti penelitian Andriansyah dan Puspita (2017) dan Efrilna (2018), sedangkan untuk pengaruh tekanan ketaatan terhadap budgetary slack juga menunjukkan hasil yang sama seperti penelitian yang dilakukan oleh Agustina dan Ones (2016) dan Baihaqi, Madani, Hatta, Maisyarah, Lucky, dan Auditya (2017). Hal lainnya dapat dikatakan jika variabel reputasi dengan tanggung jawab personal sangat jarang diteliti dan kurangnya penelitian terbaru mengenai kedua variabel ini.

Variabel pertama yaitu reputasi, merupakan pandangan atau penilaian tentang individu dari mata orang lain maupun publik (Brahmayanti dan Sholihin, 2006). Reputasi ini sendiri dapat dihubungkan dengan nilai-nilai sosial seperti kejujuran, keadilan, ataupun perbuatan curang dalam menyusun anggaran yang dilakukan oleh seseorang dan diamati oleh lingkungan sekitar. Kita tidak dapat mengontrol pendapat orang lain untuk diri kita, akan tetapi kita dapat mengontrol apa yang kita lakukan sehingga dapat mengubah pendapat orang lain terhadap diri kita (Riswandari, 2009). Penelitian yang telah dilakukan Nugrahani dan Sugiri (2004) menunjukkan bahwa reputasi berdampak negatif terhadap budgetary slack, sedangkan Abidin dan Sutrisna (2016) menemukan bahwa reputasi manajer yang meningkat ataupun tinggi maka dapat mengurangi terjadinya budgetary slack.

Variabel kedua adalah tanggung jawab personal. Menurut Mergler (2007); Efrilna (2018), tanggung jawab personal merupakan suatu kemampuan untuk dapat mengatur pikiran, perasaan maupun perilaku dengan kesediaan untuk dapat menahan diri karena tanggung jawab atas kehendak diri sendiri maupun adanya pengaruh lingkungan sekitar. Menurut Sobon (2018) suatu tanggung jawab akan muncul jika seseorang berelasi dengan orang lain, seperti atasan dengan manajer didalam perusahaan. Jika seorang manajer berpartisipasi dalam penyusunan anggaran maka secara personal akan timbul rasa bertanggung jawab atas anggaran yang telah dibuatnya. Makin tinggi keterlibatan suatu individu dalam partisipasi anggaran maka semakin tinggi pula tanggung jawab personal individu tersebut dalam 
menentukan keputusan selanjutnya (Brownell, 1982); (Andriansyah dan Puspita, 2017). Hasil penelitian Andriansyah dan Puspita (2017) serta Efrilna (2018) menunjukkan bahwa tanggung jawab personal tidak mempengaruhi budgetary slack. Temuan ini berbeda dengan temuan Stevens dan Theveranjan (2010); Andriansyah dan Puspita (2017) menunjukkan hasil bahwa tanggung jawab personal dapat mempengaruhi bawahan dalam melakukan budgetary slack.

Konflik kepentingan yang timbul antara principal dan agen ini membuat timbulnya budgetary slack yang dilakukan oleh seorang agen dengan tujuan untuk mementingkan kepentingannya daripada kepentingan perusahaan. Maka dari itulah penting bagi seorang atasan maupun principal untuk mengetahui faktor-faktor apa saja yang dapat mempengaruhi tindakan budgetary slack yang dilakukan oleh seorang bawahan atau agen. Pada penelitian ini akan menguji faktor-faktor tersebut dimana akan menguji reputasi dan tanggung jawab personal, apakah dapat mempengaruhi tindakan budgetary slack yang dilakukan agen. Sehingga rumusan masalah pada penelitian ini adalah apakah reputasi, tanggung jawab personal, dan interaksi antara reputasi dan tanggung jawab personal dapat mempengaruhi tindakan budgetary slack?.

Berdasarkan masalah tersebut, maka penelitian ini memiliki tujuan Menguji dan menganalisis pengaruh reputasi, tanggung jawab personal, dan interaksi antara reputasi dan tanggung jawab personal terhadap budgetary slack. Manfaat dari penelitian ini diharapkan dapat digunakan sebagai acuan untuk penelitian berikutnya dengan topik pengaruh reputasi dan tanggung jawab personal terhadap budgetary slack. Selain hal tersebut diharapkan mampu memberikan solusi untuk pimpinan perusahaan yang mempraktikkan participative budgeting supaya mampu mengurangi adanya tindakan budgetary slack dengan menggunakan penelitian ini sebagai salah satu acuan.

\section{Pengembangan Hipotesis \\ Pengaruh Reputasi Terhadap Budgetary Slack}

Reputasi merupakan usaha seseorang dalam membangun image dirinya sendiri terhadap pandangan orang lain. Dalam penelitian yang dilakukan oleh Baiman dan Rajan (1995); Nugrahani dan Sugiri (2004) menyatakan jika reputasi seseorang dapat menggambarkan perilaku individu yang berkaitan dengan kontrol ekonomi dan kontrol sosial. Reputasi ini sendiri dapat dihubungkan dengan norma sosial termasuk kejujuran, keadilan, dan menghindar kegagalan maupun perbuatan curang (Steven, 2002). Steven (2002) membuktikan jika seseorang yang memiliki reputasi yang tinggi cenderung untuk tidak melakukan budgetary slack. selain itu penelitian yang dilakukan oleh Nugrahani dan Sugiri (2004) menyebutkan hal yang sama dimana jika seseorang dengan reputasi yang semakin tinggi akan cenderung tidak melakukan tindakan budgetary slack. maka dapat disimpulkan jika manajer yang memiliki reputasi yang tinggi cenderung tidak melakukan tindakan budgetary slack yang merupakan tindakan yang tidak etis dibandingkan dengan manajer yang memiliki reputasi yang rendah (berpengaruh negatif).

H1: Manajer yang memiliki reputasi yang tinggi cenderung tidak melakukan budgetary slack daripada manajer yang memiliki reputasi yang rendah.

\section{Pengaruh Tanggung Jawab Personal Terhadap Budgetary Slack}

Menurut Suseno (1996:23) tanggung jawab personal adalah kesadaran individu dalam melaksanakan kewajiban yang harus mereka lakukan bersamaan dengan kebebasan pribadinya. Andriansyah dan Puspita (2017) mengatakan jika seseorang yang memiliki komitmen dalam bekerja dengan target yang ada, maka mereka akan melihat bahwa penyusunan anggaran yang benar adalah tanggung jawab yang tinggi kepada atasan dan menjauhi tindakan yang tidak etis yaitu budgetary slack. penelitian yang dilakukan oleh Stevens dan Theveranjan (2010); Andriansyah dan Puspita (2017) menyebutkan jika tanggung 
jawab personal dapat memberikan pengaruh kepada individu dalam menyusun sebuah anggaran yang baik. Pada penelitian tersebut mengatakan jika seorang agen akan merasa bersalah kepada atasannya karena telah melakukan tindakan yang tidak etis (budgetary slack). Penelitian yang dilakukan oleh Hobson, Mellon, dan Steven (2011); Propana (2019) menghasilkan seseorang yang memiliki tanggung jawab personal yang tinggi dapat mempengaruhi seseorang dalam melakukan budgetary slack karena dipandang sebagai tindakan yang tidak etis sehingga cenderung menghindari tindakan tersebut. Dapat dikatakan individu yang memiliki tanggung jawab personal tinggi akan cenderung tidak melakukan budgetary slack karena budgetary slack merupakan tindakan yang tidak etis bagi mereka (berpengaruh negatif).

$\mathrm{H} 2$ : Manajer dengan tanggung jawab personal yang tinggi akan melakukan budgetary slack lebih kecil daripada manajer dengan tanggung jawab rendah.

\section{Pengaruh Reputasi dan Tanggung Jawab Personal Terhadap Budgetary Slack}

Seorang individu yang memiliki reputasi yang tinggi dengan tanggung jawab personal yang tinggi cenderung tidak akan melakukan tindakan budgetary slack karena mereka menganggap jika tindakan tersebut merupakan perbuatan tidak etis. Reputasi dapat dilihat dari kinerja manajer yang dihubungkan dengan perilaku yang adil, jujur, maupun optimis dan adanya perbuatan curang. Seseorang dengan reputasi yang meningkat akan menghindari tindakan yang tidak etis karena ingin menjaga reputasinya, sehingga cenderung tidak melakukan budgetary slack (Nugrahani dan Sugiri, 2004). Sama halnya dengan tanggung jawab personal, dalam penelitian Andriansyah dan Puspita (2017) mengatakan jika seseorang dengan komitmen dalam bekerja untuk mencapai target yang ada, maka mereka akan melihat bahwa penyusunan anggaran yang benar merupakan suatu tanggung jawab yang tinggi kepada atasan dan menjauhi tindakan yang tidak etis yaitu budgetary slack. Selain itu, seseorang yang memiliki tanggung jawab personal akan merasa bersalah pada saat tertentu jika ingin melakukan tindakan budgetary slack yang dimana menurutnya merupakan tindakan yang tidak etis (Stevens dan Theveranjan, 2010); (Andriansyah dan Puspita, 2017). Dengan kata lain, kemungkinan tidak terjadinya slack adalah saat manajer memiliki reputasi yang tinggi dengan tanggung jawab personal yang tinggi pula.

H3: Reputasi berinteraksi dengan tanggung jawab personal dapat mempengaruhi budgetary slack.

\section{Metode Penelitian}

Desain penelitian ini merupakan desain penelitian eksperimen antar subyek $2 \times 2$ yang bertujuan untuk menguji dan menganalisis pengaruh reputasi yakni tinggi dan rendah terhadap budgetary slack. selain itu, menguji dan menganalisis pengaruh tanggung jawab personal yakni tinggi dan rendah terhadap budgetary slack. Desain penelitian eksperimen yang akan diuji dapat dilihat pada tabel dibawah ini:

Tabel 1. Desain Eksperimen 2 x 2

\begin{tabular}{|c|c|c|c|}
\hline & \multicolumn{2}{|c|}{ Reputasi } \\
\hline & & Tinggi & Rendah \\
\hline \multirow{2}{*}{$\begin{array}{l}\text { Tanggung } \\
\text { Jawab } \\
\text { Personal }\end{array}$} & Tinggi & Sel A & Sel C \\
\hline & Rendah & Sel B & Sel D \\
\hline
\end{tabular}

Sumber: Peneliti (2020)

Pada penelitian ini akan menggunakan dua variabel independen yaitu reputasi dengan tanggung jawab personal dan satu variabel dependen yaitu budgetary slack. Pengujian terhadap variabel reputasi dengan memberikan manipulasi kondisi, dimana partisipan akan berperan sebagai manajer dengan kondisi reputasi tinggi maupun reputasi rendah. Sama halnya dengan pengujian reputasi pengujian terhadap variabel tanggung jawab personal juga memberikan manipulasi kondisi, dimana partisipan akan berperan sebagai manajer dengan kondisi tanggung jawab personal tinggi maupun tanggung jawab personal rendah. Pemberian manipulasi kondisi dalam soal cerita tidak 
terikat dengan syarat tertentu, hanya sesuai dengan syarat menjadi partisipan saja yaitu telah lulus mata kuliah tertentu, untuk selanjutnya seleksi data dengan melakukan uji manipulasi yang di berikan kepada partisipan dengan tujuan untuk mengetahui mana partisipan yang membaca dengan benar atau tidak. Hasil dari uji manipulasi yang tidak lolos maka data dari partisipan tersebut tidak dapat digunakan. Untuk budgetary slack akan diberikan skema pemberian tugas yang akan di lakukan sebanyak tiga kali dengan waktu masingmasing dua menit dan menentukan target tugas produksi selanjutnya setelah melakukan tiga kali tugas produksi dengan menggunakan acuan dari hasil tugas produksi yang ketiga. Hasil dari pemberian tugas produksi tersebut akan diukur menggunakan rumus:

$$
\begin{aligned}
& \text { Budgetary Slack }=\frac{\text { hasil tugas } 3-\text { target produksi }}{\text { expected performance }} \\
& \text { Expected performance }=\frac{\text { hasil tugas } 1+\text { hasil tugas } 2}{2}
\end{aligned}
$$

Populasi penelitian ini adalah mahasiswa Universitas Katolik Widya Mandala Surabaya Program Studi Akuntansi S1. Sampel yang digunakan untuk penelitian ini menggunakan mahasiswa yang telah lulus mata kuliah penganggaran dan akuntansi manajemen, hal ini dilakukan supaya mahasiswa memahami anggaran dan dapat melakukan pengambilan keputusan penyusunan anggaran (Efrilna, 2018).

Metode pengumpulan data penelitian ini berupa penyebaran materi eksperimen dalam bentuk google form kepada mahasiswa jurusan Akuntansi S1 Universitas Katolik Widya Mandala Surabaya yang telah lulus mata kuliah penganggaran dan akuntansi manajemen, yaitu mahasiswa semester 4 atau ke atas. Aplikasi perantara peneliti dengan partisipan adalah line call atau zoom. Prosedur eksperimen dalam line call atau zoom adalah:

1. Pertama-tama partisipan akan diminta untuk masuk kedalam line call atau zoom, dimana bertujuan untuk peneliti dapat memonitor dan memberikan arahan kepada partisipan.

2. Setelah partisipan siap, partisipan diminta untuk membuka link google form dan membaca instruksi serta beberapa hal yang perlu dipatuhi selama eksperimen berjalan.

3. Setelah partisipan membaca instruksi dan peraturan kemudian partisipan diminta untuk mengisi data demografis, seperti alamat email, nama, jenis kelamin, angkatan, dan lainnya.

4. Setelah data demografis terisi, partisipan melanjutkan pada bagian berikutnya yang dimana partisipan diminta untuk membaca profil perusahaan dan peran yang diberikan kepada partisipan.

5. Setelah partisipan membaca profil perusahaan dan mengisi pertanyaan yang diberikan, partisipan diminta untuk mengisi pertanyaan mengenai uji manipulasi

6. Uji manipulasi dilakukan untuk mengetahui apakah partisipan benarbenar memahami kuesioner yang diberikan.

7. Setelah mengisi pertanyaan uji manipulasi, partisipan diminta untuk melakukan tugas produksi berupa menerjemahkan huruf ke dalam angka. Total pengerjaan tugas produksi sebanyak tiga kali dengan masingmasing tugas produksi memiliki waktu pengerjaan dua menit.

8. Setelah tugas produksi telah selesai dikerjakan, partisipan diminta untuk mengisi target produksi mereka dengan acuan tugas produksi tiga.

Pengujian hipotesis yang digunakan pada penelitian ini menggunakan analisis data analysis of variance (ANOVA). Terdapat beberapa asumsi yang diperlukan untuk melakukan pengujian ANOVA, berikut ini beberapa asumsi yang diperlukan: Homogeinty of Variance, asumsi ini untuk mengetahui apakah varian populasi data sama atau tidak. Jika nilai signifikan $\geq 0,05$ maka dapat dikatakan jika varian data adalah homogen. Yang kedua adalah Random Sampling, asumsi untuk melakukan pengujian subjek diambil secara acak, dan yang terakhir adalah Multivariate 
Normality, asumsi ini diperlukan untuk mengetahui apakah masing-masing variabel berdistribusi normal atau tidak. Jika nilai signifikansi > 0,05 maka data terdistribusi normal, begitu pula sebaliknya.

\section{Hasil dan Pembahasan \\ Test Homogenity of Variance}

Penelitian kali ini menggunakan alat uji statistic yaitu ANOVA dengan melakukan pengelolahan dalam program SPSS. Untuk ANOVA ini sendiri memiliki syarat yang harus dipenuhi sebelum data diolah lebih lanjut lagi, yaitu Homogenity of Variance. Jika data yang didapatkan dimasukkan ke dalam SPSS dan dilakukan uji Homogenity of Variance maka hasil yang akan di keluarkan adalah Levene's
Test of Error Variances. Syarat uji ANOVA sendiri memiliki yaitu hasil dari Homogenity of variance atau Levene Test memiliki nilai signifikansi diatas 0.05 (probabilitas > 0.05) yang dimana dapat dikatakan jika variannya dari data yang di uji adalah homogen, sehingga hasil yang dikehendaki adalah hasil Levene Test yang tidak signifikan atau lebih dari 0.05 (probabilitas > 0.05) (Ghozali, 2016:70). Pada tabel 2 dapat dilihat jika hasil dari Levene Test menunjukkan tingkat signifikan sebesar 0,125 yang berarti hasil tersebut tidak signifikan pada $0,05(0,125>$ $0,05)$, dapat dikatakan bahwa data memiliki variance yang sama dan memenuhi asumsi ANOVA.

Tabel 2. Levene's Test of Equality of Error Variances

\begin{tabular}{cccc}
\hline Dependent Variable: Budgetary Slack & & \\
\hline F & df1 & df2 & Sig. \\
\hline 1,994 & 3 & 56 & 0,125 \\
\hline
\end{tabular}

Tests the null hypothesis that the error variance of the dependent variable is equal across groups.

a. Design: Intercept + Reputasi + TanggungJawabPersonal + Reputasi $*$

TanggungJawabPersonal

Sumber: Data diolah (2020)

\section{Pengujian Hipotesis}

Data yang telah di uji dengan Levene Test dan memenuhi syaratnya akan dilanjutkan dengan melakukan uji ANOVA. Uji ANOVA dalam penelitian ini bertujuan untuk menguji pengaruh dari dua variabel independen dengan satu variabel dependen. Variabel independen yang pertama adalah reputasi yang dibagi menjadi dua kategori, yaitu reputasi tinggi dan reputasi rendah. Variabel independen yang kedua adalah tanggung jawab personal yang dibagi menjadi dua kategori juga, yaitu tanggung jawab personal tinggi dengan tanggung jawab personal rendah. Kedua variabel independen tersebut akan diuji untuk melihat interaksi terhadap variabel dependennya yaitu budgetary slack. Tabel 3 menyajikan hasil pengolahan data menggunakan ANOVA.

Hipotesis pertama adalah Manajer yang memiliki reputasi yang tinggi cenderung tidak melakukan budgetary slack daripada manajer yang memiliki reputasi yang rendah. Hasil dari olah data pada tabel 3 menunjukkan jika nilai $\mathrm{F}$ pada variabel reputasi sebesar 2,687 dengan tingkat signifikannya sebesar 0,107 yang dimana menunjukkan bahwa > 0,05 (tidak signifikan) sehingga dapat dikatakan bahwa variabel reputasi tidak berpengaruh terhadap budgetary slack. Dapat dilihat pada tabel 4 bahwa nilai mean untuk variabel reputasi tinggi dan variabel reputasi rendah berturut-turut adalah $-0,115$ dan -0,037 dengan selisih sebesar 0,078. Nilai mean menunjukkan angka negatif menandakan jika seorang manajer dengan reputasi yang tinggi maupun rendah, samasama tidak melakukan tindakan budgetary slack, dapat dikatakan demikian karena nilai negatif didapatkan dari penentuan target yang lebih besar daripada tugas produksi sedangkan slack ini terjadi jika seorang manajer menurunkan target untuk 
Tabel 3.Tests of Between-Subjects Effects

\begin{tabular}{lccccc}
\hline Dependent Variable: Budgetary Slack & $\begin{array}{c}\text { Type III Sum of } \\
\text { Squares }\end{array}$ & df & $\begin{array}{c}\text { Square } \\
\text { Source }\end{array}$ & F & Sig. \\
\hline Corrected Model & 0,167 & 3 & 0,056 & 1,637 & 0,191 \\
\hline Intercept & 0,346 & 1 & 0,346 & 10,191 & 0,002 \\
\hline Reputasi & 0,091 & 1 & 0,091 & 2,687 & 0,107 \\
\hline TanggungJawabPersonal & 0,058 & 1 & 0,058 & 1,696 & 0,198 \\
\hline \multicolumn{7}{l}{$\begin{array}{c}\text { Type III Sum of } \\
\text { Squares }\end{array}$} & df & $\begin{array}{c}\text { Mean } \\
\text { Square }\end{array}$ & F & Sig. \\
\hline Reputasi $*$ & 0,018 & 1 & 0,018 & 0,528 & 0,471 \\
TanggungJawabPersonal & 1,900 & 56 & 0,034 & & \\
\hline Error & 2,413 & 60 & & & \\
\hline Total & 2,067 & 59 & & & \\
\hline Corrected Total & \multicolumn{7}{|c}{0}
\end{tabular}

Sumber: Data Diolah (2020)

Tabel 4. Nilai Mean Reputasi

Dependent Variable: Budgetary Slack

\begin{tabular}{lcccc}
\hline & & & \multicolumn{2}{c}{$95 \%$ Confidence Interval } \\
\cline { 4 - 6 } Reputasi & Mean & Std. Error & Lower Bound & Upper Bound \\
\hline Reputasi Tinggi & $-0,115$ & 0,034 & $-0,182$ & $-0,048$ \\
Reputasi Rendah & $-0,037$ & 0,034 & $-0,104$ & 0,030 \\
\hline Sumber: & Data & & Diolah &
\end{tabular}

dapat memudahkan dalam pencapaian target.

Hipotesis kedua dalam penelitian ini adalah Manajer dengan tanggung jawab personal yang tinggi akan melakukan budgetary slack lebih kecil daripada manajer dengan tanggung jawab personal rendah. Berdasarkan tabel 3 dapat dilihat bahwa nilai $F$ dari variabel tanggung jawab personal sebesar 1,696 dengan tingkat signifikan variabel tanggung jawab personal sebesar 0,198, yang dimana > 0,05 (tidak signifikan) sehingga dapat dikatakan jika variabel tanggung jawab personal tidak berpengaruh terhadap budgetary slack. Pada tabel 5 dapat dilihat jika nilai mean untuk variabel tanggung jawab personal tinggi dan tanggung jawab personal rendah berturut-turut sebesar $-0,107$ dan $-0,045$ dengan selisih nilai mean tersebut sebesar 0,062 . Nilai mean dengan angka negatif menunjukkan bahwa seorang manajer dengan tanggung jawab personal tinggi maupun rendah tidak melakukan tindakan budgetaryslack

Tabel 5. Nilai Mean Tanggung Jawab Personal

Dependent Variable: Budgetary Slack

\begin{tabular}{lcccc}
\hline & & Std. & \multicolumn{2}{c}{ 95\% Confidence Interval } \\
\cline { 4 - 5 } Tanggung Jawab Personal & Mean & Error & Lower Bound & Upper Bound \\
\hline Tanggung Jawab Personal Tinggi & $-0,107$ & 0,034 & $-0,174$ & $-0,040$ \\
\hline Tanggung Jawab Personal Rendah & $-0,045$ & 0,034 & $-0,112$ & 0,022 \\
\hline Sumber: & \multicolumn{2}{c}{ Diolah } & &
\end{tabular}

Hipotesis yang ketiga adalah Reputasi berinteraksi dengan tanggung jawab personal dapat mempengaruhi budgetary slack, interakasi dari dua variabel 
tersebut yang mana dapat mempengaruhi seorang manajer untuk melakukan tindakan budgetary slack. Berdasarkan tabel 3 menunjukkan jika nilai $\mathrm{F}$ untuk interaksi antara reputasi dengan tanggung jawab personal sebesar 0,528 dengan tingkat signifikannya sebesar 0,471 yang dimana nilai signifikan tersebut lebih besar dari 0,05 yang dapat dikatakan tidak signifikan, sehingga interaksi antara variabel reputasi dengan variabel tanggung jawab personal tidak berpengaruh terhadap budgetary slack. Untuk nilai mean setiap sel mununjukkan bernilai negatif semua sehingga dapat dikatakan untuk setiap interakasi antara reputasi dengan tanggung jawab personal tidak adanya indikasi seorang manajer untuk melakukan budgetary slack.

Tabel 6. Reputasi * Tanggung Jawab Personal

Dependent Variable: Budgetary Slack

\begin{tabular}{llccccc}
\hline & Tanggung Jawab & & & Std. & \multicolumn{2}{c}{$95 \%$ Confidence Interval } \\
\cline { 6 - 8 } Reputasi & Personal & Sel & Mean & Error & Lower Bound & Upper Bound \\
\hline $\begin{array}{l}\text { Reputasi } \\
\text { Tinggi }\end{array}$ & Tanggung Jawab & A & $-0,163$ & 0,048 & $-0,258$ & $-0,068$ \\
\cline { 2 - 4 } & $\begin{array}{l}\text { Personal Tinggi } \\
\text { Persong Jawab }\end{array}$ & B & $-0,067$ & 0,048 & $-0,162$ & 0,029 \\
\hline $\begin{array}{l}\text { Reputasi } \\
\text { Rendah }\end{array}$ & $\begin{array}{l}\text { Tanggung Jawab } \\
\text { Personal Tinggi }\end{array}$ & C & $-0,051$ & 0,048 & $-0,146$ & 0,045 \\
\cline { 2 - 5 } & $\begin{array}{l}\text { Tanggung Jawab } \\
\text { Personal Rendah }\end{array}$ & D & $-0,023$ & 0,048 & $-0,119$ & 0,072 \\
\hline Sumber: & \multicolumn{2}{c}{ Data } & \multicolumn{2}{c}{ Diolah } & $(2020)$
\end{tabular}

\section{Pengaruh Reputasi Terhadap Budgetary} Slack

Penelitian kali ini bertujuan untuk mengetahui apakah variabel reputasi dapat mempengaruhi tindakan budgetary slack. Dengan hipotesis yang pertama adalah Manajer yang memiliki reputasi yang tinggi cenderung tidak melakukan budgetary slack daripada manajer yang memiliki reputasi yang rendah. Reputasi merupakan usaha seseorang dalam membangun image dirinya sendiri terhadap pandangan orang lain. Reputasi seseorang dapat menggambarkan perilaku individu yang berkaitan dengan kontrol ekonomi dan kontrol sosial. Reputasi ini sendiri dapat dihubungkan dengan norma sosial termasuk kejujuran, keadilan, dan menghindar kegagalan maupun perbuatan curang (Steven, 2002). Hasil dari penelitian ini menunjukkan hasil bahwa variabel reputasi tidak signifikan terhadap budgetary slack, yang berarti variabel reputasi sendiri tidak berpengaruh terhadap budgetary slack. Hasil yang tidak signifikan menandakan jika manajer dengan reputasi rendah maupun tinggi tidak akan melakukan budgetary slack karena dianggap mementingkan kepentingan perusahaan dan menyelesaikan tugas yang diberikan dengan tingkat resiko yang rendah pula. Hasil penelitian ini juga menunjukkan nilai mean yang negatif. Hasil tersebut menunjukkan bahwa seorang manajer dengan reputasi tinggi maupun rendah tidak melakukan yang menyimpang, seperti budgetary slack untuk mempermudah dalam menyelesaikan tugasnya dan cenderung untuk mempertim-bangkan resiko yang akan diterima jika melakukan hal tersebut. Hal tersebut dapat dikatakan demikian karena hasil negatif didapatkan dari target lebih tinggi daripada tugas produksi yang diberikan, sedangkan budgetary slack timbul karena manajer melakukan penurunan target yang ada.

\section{Pengaruh Tanggung Jawab Personal Terhadap Budgetary Slack}

Hipotesis kedua dalam penelitian kali ini adalah Manajer dengan tanggung jawab personal yang tinggi akan melakukan budgetary slack lebih kecil daripada manajer dengan tanggung jawab personal 
rendah. Menurut Suseno (1996:23), tanggung jawab personal adalah kesadaran dari tiap individu dalam melakukan sesuatu yang sudah menjadi kewajiban yang harus mereka lakukan bersamaan dengan kebebasan pribadinya. Hasil dari penelitian ini menunjukkan hasil bahwa variabel tanggung jawab personal tidak signifikan terhadap budgetary slack yang dapat dikatakan bahwa variabel tanggung jawab personal tidak berpengaruh terhadap tindakan budgetary slack. Untuk hasil yang tidak signifikan menandakan jika seorang manajer dengan tanggung jawab personal rendah maupun tinggi tidak melakukan tindakan budgetary slack karena menganggap tugas diberikan merupakan tanggung jawab mereka untuk menyelesaikannya dengan baik dan mementingkan kepentingan perusahaan juga. Hasil untuk nilai mean tanggung jawab tinggi dan tanggung jawab rendah menunjukkan nilai yang negatif, hal tersebut menandakan jika seorang manajer walaupun memiliki tanggung jawab rendah maupun tinggi akan cenderung untuk tidak melakukan tindakan budgetary slack karena nilai negatif menunjukkan jika target yang ditetapkan oleh partisipan lebih tinggi dari tugas produksi mereka, dimana budgetary slack ini seharusnya timbul karena manajer melakukan penurunan target sehingga dapat dikatakan tidak adanya indikasi budgetary slack. Hal ini menandakan jika seorang manajer dengan tanggung jawab rendah ataupun tinggi cenderung untuk mementingkan tanggung jawab mereka atas tugas yang diberikan dan mementingkan kepentingan perusahaan.

\section{Pengaruh Reputasi dan Tanggung Jawab Personal Terhadap Budgetary slack}

Hipotesis ketiga sekaligus hipotesis terakhir dalam penelitian ini adalah manajer yang memiliki tingkat reputasi tinggi ataupun rendah dengan tingkat tanggung jawab personal tinggi atau rendah dapat mempengaruhi tindakan budgetary slack. Tujuan dari hipotesis ini adalah untuk mengetahui apakah interaksi antara variabel reputasi dengan variabel tanggung jawab personal dapat mempengaruhi tindakan budgetary slack. Penelitian kali ini menunjukkan hasil bahwa interaksi antara variabel reputasi dengan tanggung jawab personal tidak dapat mempengaruhi tindakan budgetary slack, yang dapat dilihat dari nilai signifikan untuk interaksi antara variabel reputasi dengan tanggung jawab personal pada tabel 4.6. Hasil tidak signifikan ini menunjukkan bahwa seorang manajer dengan reputasi yang rendah maupun tinggi dan tanggung jawab personal yang rendah maupun tinggi tidak akan melakukan tindakan budgetary slack karena menganggap tindakan tersebut tidak patut untuk dilakukan dan memiliki resiko yang tinggi juga jika diketahui oleh atasannya. Hasil untuk nilai mean setiap selnya menunjukkan nilai yang negatif yang menandakan jika interaksi reputasi dan tanggung jawab personal setiap selnya tidak ada indikasi budgetary slack karena budgetary slack timbul karena manajer melakukan penurunan target sedangkan pada penelitian kali ini hasil dari partisipan menentukan target lebih tinggi atau sama dengan tugas produksinya sehingga dari sinilah timbul nilai mean yang negatif.

\section{Simpulan}

Berdasarkan dari hasil penelitian yang telah dilakukan maka dapat disimpulkan bahwa variabel reputasi yang dilakukan uji parsial menunjukkan tidak berpengaruh terhadap tindakan budgetary slack. Variabel reputasi ini dibagi menjadi dua, yaitu tinggi dan rendah. Nilai mean kedua kategorial tersebut memiliki nilai negative sehingga dapat dikatakan kedua kategorial tersebut tidak dapat menciptakan slack, sehingga dapat disimpulkan jika hipotesis pertama ditolak

Variabel tanggung jawab personal dengan uji parsial menunjukkan tidak berpengaruh terhadap tindakan budgetary slack. Variabel tanggung jawab personal dibagi menjadi dua kategorial, yaitu tinggi dan rendah. Kedua kategorial tersebut menunjukkan nilai mean yang negative sehingga dapat dikatakan kedua kategorial tersebut tidak dapat menciptakan slack, sehingga dapat dikatakan jika hipotesis kedua ditolak. 
Interaksi antara reputasi dengan tanggung jawab personal menunjukkan hasil bahwa tidak dapat mempengaruhi tindakan budgetary slack, sehingga dapat dikatakan jika hipotesis ketiga dalam penelitian ini ditolak.

Penelitian yang dilakukan ini ditemukan beberapa keterbatasan yang ada, maka peneliti memberikan saran untuk penelitian berikutnya, yaitu yang pertama, penelitian selanjutnya dengan berbasis online dapat membatasi partisipan per pertemuan zoom sehingga penjelasan dari peneliti memungkinkan tersampai dengan jelas dan tidak terlalu lama untuk menunggu hingga semua siap untuk melakukan eksperimen. Yang kedua, penelitian selanjutnya dapat menggunakan asisten peneliti dalam melakukan pengumpulan data dari partisipan sehingga informasi yang didapatkan partisipan tanpa adanya campur tangan peneliti.

\section{Daftar Pustaka}

Abidin, D., \& Sutrisna, A. (2016). Pengaruh Nonbinding Budgetary Announcement, Reputasi, Etika, dan Self-Esteem Pada Budgetary Slack. Tirtayasa Ekonomika, 11(1), $1-11$.

Agustina, Y., \& Ones, R. (2016). Pengaruh Tekanan Ketaatan dan Self-esteem Terhadap Budgetary Slack. Jurnal Ilmiah Gema Ekonomi, 6(1), 779796.

Andriansyah, B., \& Puspita, L. (2017). Pengaruh Pemberian Insentif dan Tanggung Jawab Personal Terhadap Budgetary Slack. Simposium Nasional Akuntansi, 118.

Anthony, R. N. \& Govindarajan, V. (2011). Sistem Pengendalian Manajemen (edisi-11). Jakarta: Salemba Empat.

Baihaqi, Madani, Hatta, Maisyarah, Lucky, \& Auditya. (2017). Pengaruh Tekanan Ketaatan dan Tanggung Jawab Persepsian Terhadap Budgetary Slack. Simposium
Nasional Akuntansi XX, Jember, 2017.

Baiman, S., \& Rajan, M. (1995). The Informational Advantages of Discretionary Bonus Schemes. Accounting Review, 70, 557-579.

Brahmayanti, S., \& Sholihin, M. (2006). Pengaruh Reputasi Dalam Hubungan Antara Asimetri Informasi Dengan Senjangan Anggaran Dibawah Metode Kompensasi Truth Inducing. Jurnal Ekonomi dan Bisnis Indonesia, 21(2), 175-185.

Brownell, P. (1982). The Role of Accounting Data in Performance Evaluation, Budgetary Participation, and Organizational Effectiveness. Journal of Accounting Research, 20 (1), 1227.

Damayanti, I. G., \& Wirasedana, I. W. (2014). Pengaruh Partisipasi Anggaran, Reputasi, dan Etika Pada Kesenjangan Anggaran Pada SKPD Di Pemerintahan Kota Denpasar. EJurnal Akuntansi Universitas Udayana, 9(1), 133-142.

Efrilna, P. (2018). Pengaruh Skema Pemberian Insentif dan Tanggung Jawab Personal Terhadap Budgetary Slack. Jurnal Akuntansi, $6(1), 1-21$.

Ghozali, I. (2016). Aplikasi analisis multivariative dengan program IBM SPSS 23 (edisi ke-8). Semarang: Badan Penerbit Universitas Diponegoro.

Hansen, D., \& Mowen, M. (2016). Akuntansi Manajerial (edisi-8). Jakarta: Salemba Empat.

Hudayati, A. (2002). Perkembangan Penelitian Akuntansi Keperilakuan: Berbagai Teori dan Pendekatan Yang Melandasi. Jurnal Akuntansi Keperilakuan, 6(2), 81-96

Hobson, J. L., Mellon, M., \& Steven, D. (2011). Determinants of Moral Judgments Regarding Budgetary Slack: An Experimental Examination of Pay Scheme and Personal Values. Behavioral 
Research in Accounting, 23(1), 87107.

Jensen, M., \& Meckling, W. (1976). Theory of The Firm: Managerial Behavior, Agency Costs and Ownership Structure. Journal of Financial Economics, 3, 305-360.

Mergler, A. (2007). Personal Responsibility: The Creation, Implementation and Evaluation of a School-Based Program. The Journal of Student Wellbeing, 1333.

Nugrahani, T. S., \& Sugiri, S. (2004). Pengaruh Reputasi, Etika, dan SelfEsteem Terhadap Budgetary Slack di Bawah Asimetri Informasi. Jurnal Ekonomi dan Bisnis Pengaruh Indonesia, 19 (4), 375388.

Onsi, M. (1973). Factor Analysis of Behavioral Variables Affecting Budgetary Slack. The Accounting Review, 48, 535-548.

Propana, F. (2019). Pengaruh Pemberian Insentif, Tanggung Jawab Personal dan Nilai Personal Terhadap Budgetary Slack. Diambil kembali dari (Disertasi, Program Pascasarjana Universitas Katolik Widya Mandala Surabaya, Surabaya, Indonesia).

Riswandari, E. (2009). Pengaruh Reputasi, Etika dan Persepsi Keadilan Terhadap Kesenjangan Anggaran (Budgetary Slack). Jurnal Akuntansi Bisnis, 2(1), 33-50.

Sobon, K. (2018). Konsep Tanggung Jawab Dalam Filsafat Emmanuel Levinas. Jurnal Filsafat, 28(1), 47-73.

Steven, D. (2002). The Effects Of Reputation and Ethics On Budgetary Slack. Journal Of Management Accounting Research, 14, 153-171.

Steven, D., \& Thevaranjan, A. (2010). A Moral Solution to The \&Moral Hazard Problem. Accounting Organization and Society, 35, 125139.

Supriyono, R. (2018). Akuntansi Keperilakuan. Yogyakarta: Universitas Gadjah Mada.
Suseno, F. (1996). Etika Sosial. Jakarta: Gramedia Pustaka Utama. 